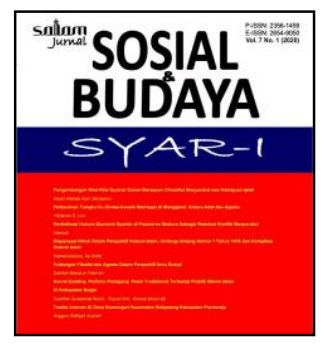

P-ISSN: 2356-1459. E-ISSN: 2654-9050

Vol. 8 No. 2 (2021), pp. 487-498

DOI: 10.15408/sjsbs.v8i2.20193

http://journal.uinjkt.ac.id/index.php/salam/index

\title{
Peran Uem Le'u \\ Dalam Kehidupan Masyarakat Suku Amaf \\ Pada Sonaf Maubesi Kecamatan Insana*
}

\author{
Asti Yunita Benu ${ }^{5}$ \\ Universitas Citra Bangsa Kupang, NTT \\ do \\ 10.15408/sjsbs.v8i2.20193
}

\begin{abstract}
:
One of the cultural results in people's life that is thick with cultural heritage is the traditional house. Houses in general have a function as a place of shelter, rest and activity. The house, as a place where a group of people has lived for a long time, has undergone various changes. The changes that occur are seen in the form, meaning, function and value of the house. The traditional houses of the people in East Nusa Tenggara are diverse in form and function and are integrated into social life. One of them is a traditional house which is also called a sacred house as a form of community culture in North Central Timor Regency. This study aims to identify and describe the perspective of the Amaf tribe in Sonaf Maubesi, Insana District towards the existence of Uem Le'u and the role of Uem L'eu in various aspects of the life of the Amaf tribe in Sonaf Maubesi, Insana District. This study uses a qualitative approach that is descriptive. The type of data needed in this study is primary data and secondary data and the instruments used to obtain data in this study are the researchers themselves because researchers are the primary data collection tools. Data collection techniques used were interview techniques, questionnaires and documentation. While the data analysis technique used in this study is a qualitative descriptive analysis technique. This technique will be developed by means of Interpretative Versthehen, meaning that all the data obtained are grouped based on themes or categories and then analyzed partially. From the research carried out, the results of this study show that the Amaf tribe in Sonaf Maubesi, Insana TTU sub-district still has a sacred perspective, which is full of meanings and customs and beliefs in the existence of Uem Le'u. In the aspect of religion or belief, the people of the Amaf tribe today still believe that Uem Le'u is the place where God is believed to reside and the dwelling place of the ancestors who inhabited heaven or the final resting place. Meanwhile, in the social aspect, Uem Le'u is still a gathering place for the Amaf people from various groups or strata of society to carry out a traditional ceremony related to the beliefs of the local community.
\end{abstract}

Keywords: Culture; Custom home

\begin{abstract}
Abstrak:
Salah satu hasil kebudayaan dalam kehidupan masyarakat yang kental akan pewarisan budaya yaitu rumah adat. Rumah pada umumnya memiliki fungsi sebagai tempat berteduh, beristrahat dan beraktifitas. Rumah sebagai tempat yang ditinggali sekolompok manusia dalam jangka waktu yang lama, telah mengalami berbagai perubahan. Perubahan yang terjadi dilihat pada bentuk, makna, fungsi serta nilai dari rumah tersebut. Rumah adat
\end{abstract}

* Received: January 25, 2021, Revision: January 30, 2021, Published: April 1, 2021.

${ }^{5}$ Asti Yunita Benu adalah Dosen Fakultas Keguruan dan Ilmu Pendidikan, Universitas Citra Bangsa Kupang. E-mail: astiyunitabenu@gmail.com 
masyarakat di Nusa Tenggara Timur memiliki keberagaman dalam bentuk dan fungsi serta menyatu dalam kehidupan bermasyarakat. Salah satunya adalah rumah adat yang juga disebut rumah keramat sebagai wujud budaya masyarakat di Kabupaten Timor Tengah Utara. Penelitian ini bertujuan untuk mengidentifikasi dan mendeskripsikan tentang Perspektif suku Amafdi Sonaf Maubesi Kecamatan Insana terhadap eksistensi Uem Le'u dan Peran Uem L'eu dalam berbagai aspek kehidupan masyarakat suku Amaf di Sonaf Maubesi Kecamatan Insana. Penelitian ini menggunakan pendekatan kualitatif yang bersifat deskriptif. Jenis data yang dibutuhkan dalam penelitian ini yaitu data primer dan data sekunder serta instrumen yang dipakai untuk mendapatkan data dalam penelitian ini adalah peneliti sendiri karena peneliti merupakan alat pengumpul data utama. Teknik pengumpulan data yang digunakan adalah teknik wawancara, angket dan dokumentasi. Sedangkan teknik analisis data yang digunakan dalam penelitian ini adalah teknik analisis deskriptif kualitatif. Teknik ini akan dikembangkan dengan cara verstheheninterpretative artinya semua data yang diperoleh dikelompokkan berdasarkan tema atau kategori kemudian dianalisis secara parsial. Dari penelitian yang dilaksanakan maka hasil penelitian ini yaitu masyarakat suku Amaf di Sonaf Maubesi Kecamatan Insana TTU masih memiliki perspektif yang sakral, yang sarat akan makna dan adat istiadat serta kepercayaan terhadap eksistensi Uem Le'u. Dalam aspek agama atau kepercayaan, masyarakat suku Amaf pada saat ini masih percaya bahwa Uem Le'u merupakan tempat bersemayamnya Tuhan yang dipercayai dan tempat tinggalnya para leluhur yang mendiami surga atau tempat peristirahatan terakhir. Sedangkan pada aspek sosial Uem Le'u masih merupakan tempat berkumpulnya masyarakat suku Amaf dari berbagai golongan atau strata masyarakat guna melaksanakan suatu upacara adat yang berkaitan dengan kepercayaan masyarakat setempat.

Kata Kunci: Kebudayaan; Rumah Adat

\section{A. PENDAHULUAN}

Indonesia merupakan negara kepulauan terdiri dari berbagai suku bangsa. Realita keberagaman menunjukan bahwa kehidupan masyarakat begitu majemuk dan beraneka ragam. Kemajemukan masyarakat Indonesia tercermin dalam berbagai hasil kebudayaan yang lebur dalam kehidupan bermasyarakat. Hasil kebudayaan masyarakat yang bersifat konkrit maupun abstrak terpelihara dan diwariskan dari generasi ke generasi. Salah satu hasil kebudayaan dalam kehidupan masyarakat yang kental akan pewarisan budaya itu sendiri yaitu rumah adat. Pada kemajemukan suku bangsa yang ada di Indonesia juga memberi arsitektur dan fungsi rumah adat berbedabeda sesuai kehidupan masyarakat suku tersebut.

Rumah pada umumnya memiliki fungsi sebagai tempat berteduh, beristrahat dan beraktifitas. Rumah sebagai tempat yang ditinggali sekolompok manusia dalam jangka waktu yang lama, telah mengalami berbagai perubahan. Perubahan yang terjadi dilihat pada bentuk, makna, fungsi serta nilai dari rumah tersebut. Namun rumah dalam kehidupan masyarakat berbudaya juga tidak dipandang sebatas tempat tinggal, tetapi dipandang dan diposisikan sebagai pandangan hidup serta ekspresi dari kehidupan suatu kelompok masyarakat itu sendiri. Hal ini sejalan dengan pendapat Faisal (2014) mengemukakan bahwa rumah adat tradisional merupakan bangunan rumah yang mencirikan atau khas bangunan suatu daerah di Indonesia yang melambangkan kebudayaan dan ciri khas masyarakat setempat. Hingga saat ini masih banyak suku atau daerah-daerah di Indonesia yang masih memperhatikan rumah adat sebagai usaha untuk memelihara nilai-nilai budaya. 
Rumah sebagai tempat yang ditinggali sekelompok manusia dalam jangka waktu yang lama, telah mengalami berbagai perubahan. Perubahan yang terjadi dilihat pada bentuk, makna, fungsi serta nilai dari rumah tersebut. Namun rumah dalam kehidupan masyarakat berbudaya juga tidak dipandang sebatas tempat tinggal, tetapi dipandang dan diposisikan sebagai pandangan hidup serta ekspresi dari kehidupan suatu kelompok masyarakat itu sendiri. Rumah adat masyarakat di Nusa Tenggara Timur memiliki keberagaman dalam bentuk dan fungsi serta menyatu dalam kehidupan bermasyarakat. Suku-suku yang berada di Nusa Tenggara Timur memiliki rumah adat sebagai hasil budaya dengan beberapa bentuk yang sedikit berbeda. Namun pada umumnya setiap kelompok masyarakat atau suku memiliki rumah adat dengan bentuk bulat atau setengah lingkaran.

Rumah adat dalam kehidupan masyarakat NTT dipercaya sebagai tempat keramat atau bersemayamnya roh nenek moyang atau bersemayamnya sang pencipta kehidupan. Salah satunya adalah rumah adat yang juga disebut rumah keramat sebagai wujud budaya masyarakat di Kabupaten Timor Tengah Utara.

Struktur sosial budaya masyarakat Kabupaten TTU terbagi dalam beberapa suku yang terstruktur dalam pembagian Sonaf. Sekian jumlah suku yang berada dalam suatu Sonaf memposisikan rumah adat dengan fungsi yang berbeda-beda, yang kemudian fungsi tersebut melebur dalam kehidupan bermasyarakat. Keberadaan rumah adat sebagai salah satu hasil budaya yang terbentuk dalam kehidupan masyarakat Indonesia khususnya di berbagai daerah NTT mulai memudar pengenalan dan pelestariannya. Hal ini disebabkan oleh perkembangan zaman dan iptek yang belum seimbang dengan pola pikir dan kehidupan bermasyarakat di sebagian besar daerah NTT. Sehingga memberi dampak pergeseran atau alih fungsi pada eksistensi rumah adat tersebut.

Pada awal zaman, rumah hanya sebagai tempat tinggal namun seiring perkembangan, rumah kemudian dibangun secara terpisah sebagai tempat bersemayamnya roh nenek moyang. Rumah yang dibangun tersebut dipercayai menjadi tempat bersemayamnya roh nenek moyang yang memiliki kekuatan untuk mengatur setiap aspek kehidupan manusia. Rumah tersebut dikenal sebagai rumah adat. Rumah adat masyarakat di Nusa Tenggara Timur memiliki keberagaman dalam bentuk dan fungsi serta menyatu dalam kehidupan bermasyarakat. Salah satunya adalah rumah adat yang juga disebut rumah keramat sebagai wujud budaya masyarakat di Kabupaten Timor Tengah Utara. Masyarakat Kabupaten TTU terbagi dalam beberapa suku yang terstruktur dalam pembagian Sonaf. Sekian suku di dalam suatu Sonaf memposisikan rumah adat dengan fungsi yang berbeda-beda, yang melebur dalam kehidupan bermasyarakat.

Keberadaan rumah adat sebagai salah satu hasil budaya yang terbentuk dalam kehidupan masyarakat Indonesia khususnya di berbagai daerah NTT mulai memudar pengenalan dan pelestariannya. Hal ini disebabkan oleh perkembangan zaman dan iptek yang belum seimbang dengan pola pikir dan kehidupan bermasyarakat di sebagian besar daerah NTT. Sehingga memberi dampak pergeseran atau alih fungsi pada eksistensi rumah adat tersebut. Oleh karena itu semestinya kekayaan budaya 
melalui hasil kebudayaan yang diturunkan dari generasi ke generasi harus diperkenalkan secara berkala.

Melihat fenomena pergeseran fungsi bahkan terjadinya perubahan bentuk fisik rumah adat akibat perkembangan zaman maka penelitian ini akan menyajikan deskripsi dari salah satu hasil budaya yang patut dipertahankan sebagai identitas masyarakat. Penelitian ini bertujuan untuk mengidentifikasi dan mendeskripsikan tentang Perspektif suku Amafdi Sonaf Maubesi Kecamatan Insana terhadap eksistensi Uem Le'u dan Peran Uem L'eu dalam berbagai aspek kehidupan masyarakat suku Amaf di Sonaf Maubesi Kecamatan Insana.

\section{Kerangka Teori}

\section{Kebudayaan}

Kata kebudayaan berasal dari bahasa Sansekerta, buddayah, bentuk jamak dari budhi yang berarti "budi" atau "kekal". Kebudayaan adalah seluruh system gagasan dan rasa, tindakan, serta karya yang dihasilkan manusia dalam kehidupan bermasyarakat yang ${ }^{6}$ dijadikan miliknya dengan belajar. Budaya yang ada pada saat ini telah mengalami banyak perubahan yang diakibatkan oleh modernisasi yang semakin berkembang pesat serta globalisasi yang sangat kuat pengaruhnya hingga mempengaruhi kehidupan serta mengubah kebudayaan masyarakat tradisionalnya. ${ }^{3}$

Kata kebudayaan dapat disamakan dengan culture (bahasa Inggris), dan tsaqafah (bahasa Arab), artinya lebih menekankan aspek rasional dan moral. ${ }^{4} \mathrm{M}$. Abdul Karim mengatakan bahwa kata kebudayaan merupakan kata benda abstrak hasil penambahan 'ke' dan akhiran 'an' dari kata budaya yang memiliki pengertian yang sama dengan kultur dalam artian sebagai usaha otak manusia atau akal budi.

Perubahan yang dinginkan dari kebudayaan adalah perubahan yang tetap memelihara karakter inti dan menyesuaikannya dengan kondisi saat ini, sehingga benang merah masa lalu tetap terjaga, masa kini dan masa yang akan dating. ${ }^{5}$ Ruang lingkup perubahan sosial meliputi unsur-unsur budaya materiil dan immateril, artinya setiap unsur budaya masyarakat yang bersifat materiil dan immateriil (spirituil) juga cenderung terhadap perubahan. Berbeda dengan apa yang disampaikan oleh Kingsley Davis yang mengartikan perubahan sosial sebagai perubahan-perubahan yang terjadi dalam struktur dan fungsi masyarakat sehingga akan disebut suatu perubahan sosial kalau tatanan dan fungsi dalam masyarakat yang berubah. ${ }^{6}$ Sebagai contoh ketika muncul persatuan pekerja atau organisasi buruh yang dalam masyarakat kapitalis

2,3 Boru, Jeky El. 2013. Perkembangan Arsitektur Vernakular Atoni Studi Kasus: Kawasan Istana Kerajaan Amarasi di Tunbaun, Kabupaten Kupang. Jurnal Arsitektur KOMPOSISI, 10, 3, 207-216

${ }^{4}$ M. Abdul Karim, 2009, Sejarah Pemikiran dan Peradaban Islam, Yogyakarta: Pustaka BOOK Publisher, 2009, hlm.34.

5 A. B Sarjono, 2011. Arsitektur dalam perubahan kebudayaan. (online), Tersedia: Dtap.undip.ac.id/index.php/artikel/arsitektur-dalam-perubahan-kebudayaan-studi-kasus (diunduh januari 2021)

6 Syamsidar. 2015. Dampak Perubahan Sosial Budaya terhadap Pendidikan. Jurnal: Bimbingan Penyuluhan Islam, 2, 1, 83-92 
menyebabkan perubahan hubungan antar pekerja dengan majikan yang kemudian berimplikasi juga pada berubahnya organisasi ekonomi atau bahkan politik (pada negara tertentu ada yang berubah menjadi partai politik, misalnya partai buruh di Inggris).

\section{Rumah Adat:}

Menurut Prabowo, dkk, rumah merupakan tempat tinggal manusia. Rumah adat adalah rumah yang memiliki ciri khas bangunan suatu daerah di Indonesia yang melambangkan kebudayaan suatu daerah. ${ }^{7}$ Sedangkan menurut Kristiani mengemukakan bahwa Rumah adat adalah rumah khas dari berbagai suku di Indonesia yang merupakan warisan budaya yang sangat berharga. Sehingga perlu dijaga, dirawat dan dilestarikan oleh segenap manusia. ${ }^{8}$ Djono, dkk mengemukakan bahwa bangunan tradisi atau rumah adat merupakan salah satu wujud budaya yang bersifat konkret. Dalam konstruksinya setiap bagian atau ruang dalam rumah adat sarat dengan nilai dan norma yang berlaku pada masyarakat pemilik kebudayaan tersebut. ${ }^{9}$ Sejalan dengan itu, Hutari mengatakan bahwa bentuk arsitektur sebuah bangunan tak bisa lepas dari situasi masyarakat pendukung dan keadaan lingkungannya. ${ }^{10}$

Beberapa pendapat ini sejalan dengan penelitian yang dilakukan oleh ${ }^{11}$ Jeky El Boru (2013) mengenai "Perkembangan arsitektur vernakular Atoni". Pada hasil penelitian ini mendeskripsikan tentang rumah Raja/Sonaf, rumah rakyat biasa/ Ume to Ana, dan rumah Marga/ Le'u. Pada pembangunannya menggunakan ritual yang dipimpin oleh kepala kampung (Kanaf) dengan hewan sembelihan sebagai kurban untuk meminta perlindungan dari Uis Neno (yang Mahakuasa).

Selain itu juga sejalan dengan penelitian yang dilakukan oleh Ferdy Sabono mengenai 'Konsep rumah tumbuh pada rumah adat tradisional dusun Doka, Nusa Tenggara Timur'. Secara umum arah pengembangan rumah tumbuh yang dilakukan oleh masyarakat pada rumah adat di dusun Doka menggunakan pengembangan ke arah horisontal. Konsep ini disesuaikan dengan penempatan ruang-ruang pembentuk utama yakni Teda Wari, Teda Wawo dan One yang telah memiliki urutan yang baku

7 R. Prabowo, T. Listyorini, and A. Jazuli. 2011. Pengenalan Rumah Adat Indonesia Berbasis Augmented Reality dengan Memanfaatkan KTP Sebagai Marker. Jurnal SNATIF, 2,51-58

8 D. Kristiani. 2014. Ensiklopedia Negeriku Rumah Adat. Jakarta: Bhuana Ilmu Populer

9 Djono., Utomo Tri Prasetyo., \& Subiyantoro Slamet. 2012. Nilai Kearifan Lokal RumahTradisional Jawa. Dalam Jurnal Humaniora, 24(3): 269-278

${ }^{10}$ Hutari, Fandy. 2017. Hiburan Masa Lalu dan Tradisional Lokal: Kumpulan Esai Seni, Budaya dan Sejarah Indonesia. Yogyakarta: INSIST Press. Hal 62

${ }^{11}$ Boru, Jeky El. 2013. Perkembangan Arsitektur Vernakular Atoni Studi Kasus: Kawasan Istana Kerajaan Amarasi di Tunbaun, Kabupaten Kupang. Jurnal Arsitektur KOMPOSISI, 10, 3, 207-216

12 Sabono Ferdy. (2017). Konsep Rumah Tumbuh Pada Rumah Adat Tradisional Dusun Doka,Nusa Tenggara Timur. MEDIA MATRASAIN Vil.14 No.1,Maret ISSN 1858-1137

${ }^{13}$ Anra Yusdi dan Asyhadi. (2018). Architecture Varieties of Jambi Malay Traditional House: A study ofarchitectural archeology in conserving cultural heritage and advancement of Jambi Malay culture. TITIAN Vol.2 No.2 Desember Hal 300-322 
sehingga konsep pengembangan hanya dapat dilakukan pada sisi kiri, kanan dan belakang rumah. ${ }^{12}$

Serta penelitian ${ }^{13}$ Yusdi Anra dan Asyhadi mengenai "Architecture varieties of Jambi Malay traditional house. Rumah tradisional perahu berada di area rumah penduduk Desa Tanah Periuk. Rumah tersebut tepatnya berada dekat rumah Datuk Rio (Kepala Desa) yang berjarak 2 rumah. Rumah tradisional tanah periukterdiri dari ornament dan pembagian pola tata ruang. Masing-masing ornament dan tata ruang yang diciptakan atau yang direkayasa oleh masyarakat Jambi disesuaikan dan diperuntukkanpada fungsi-fungsi tertentu, yang secara lebih rinci dijabarkan sebagai berikut (1) Anak tangga, untuk menaik masuk dalam rumah; (2) Ruang bawah/luar, untuk tempat beternak, tempatnya memasak/dapur, tempatnya meletakkan bendabenda sepertialat kerja, kayu, sepeda dan alat memasak; (3) Ruang tamu/dalam rumah, untuk bermusyawarah memecahkan sebuah masalah yang ada, yang dirembuk oleh ninik, orang tua, anak, dan tamu (warga tetangga yang bertamu); (4) Kamar satu, tempat tidur menantu; (5) Kamar dua, tempatnya orang tua; (6) Ruang depan kamar dua, untuk memasak/dapur; (7) Ruang atap atas/dek rumah, untuk meletakkan barang, alat-alat dapur atau meletakkan masakan (acara pernikahan, khitanan atau acara lainnya); (8) Tiga jendela yang berfungsi untuk mendapatkan udara/angin.

Liliweri menjelaskan bahwa arsitektur Indonesia dipengaruhi oleh keanekaragaman budaya, sejarah dan geografi di Indonesia ${ }^{14}$. Sejalan dengan Ariani yang mengatakan bahwa di Indonesia jenis dan bentuk rumah adat sangat banyak jumlahnya dan beraneka ragam. Rumah adat mengekspresikan semangat dan jiwa yang terkandung di dalam masyarakat. Ekspresi semangat dan jiwa masyarakat menyebabkan bentuk dan organisasi rumah adat dipengaruhi oleh budaya yang melatarbelakanginya ${ }^{15}$.

Beberapa pendapat ini sejalan dengan penelitian yang dilakukan oleh ${ }^{16}$ Mario $\mathrm{Y}$ Kabosu, mengenai "Arsitektur rumah adat Sonaf Bikomi-Sanak pada masyarakat Maslete Kabupaten Timor Tengah Utara Nusa Tenggara Timur"; Bentuk arsitektur rumah adat Sonaf Bikomi-Sanak secara garis besar pada bagian atapnya menyerupai perahu terbalik, dan ilalang yang telah kering sebagai penutup atapnya. Dasar untuk rumah adat Sonaf Bikomi-Sanak bukanlah keramik ataupun papan melainkan tanah. Bentuk bangunan rumah adat SonafBikomi-Sanak memiliki makna sebagai mana menurut pandangan kehidupan masyarakat melambangkan alam semesta dan pemersatu suku. Sementara untuk dinding yang menutupi rumah adat ini adalah papan. Baik itu ilalang, papan-papan yang digunakan untuk menutupi rumah adat serta kayu-kayu yang digunakan dalam pembuatan rumah adat Sonaf Bikomi-Sanak merupakan bahan-bahan yang terpilih berdasarkan hasil kesepakatan bersama sebelum mendirikan rumah adat ini. Sonaf Bikomi-Sanak, konstruksi bangunannya khas dengan fungsi setiap bagian yang berbeda satu sama lain mengandung unsur filosofis yang sarat akan nilai-nilai.

Serta oleh Dahliani mengenai 'Eksistensi rumah tradisional Banjar sebagai identitas kawasan bersejarah di Kelurahan Kuin Utara, Banjarmasin'. Kondisi bentuk rumah di kawasan studi ini lebih didominasi oleh rumah yang berbentuk masa kini 
sehingga keberadaan rumah tradisional jadi tenggelam. Rumah yang ditempati oleh penduduk kebanyakan adalah rumah warisan. Pada asalnya berbentuk rumah tradisional yang kemudian diperbaiki karena kualitas bahan yang memprihatinkan dan menyesuaikan dengan kebutuhan penghuni sekarang. ${ }^{17}$

\section{METODE PENELITIAN}

Penelitian ini menggunakan pendekatan kualitatif yang bersifat deskriptif. Penelitian ini akan mengidentifikasi dan mendeskripsikan secara holistik dan komprehensif tentang peran $U e m L e^{\prime} u$ dalam kehidupan masyarakat suku Amaf pada Sonaf Maubesi Kecamatan Insana Kabupaten TTU. Penelitian ini akan dilaksanakan di Kecamatan Insana yang berada di Kabupaten Timor Tengah Utara Provinsi Nusa Tenggara Timur. Jenis data yang dibutuhkan dalam penelitian ini yaitu data primer yang diperoleh dari informan melalui wawancara dan data sekunderyaitu data yang diperoleh dari observasi dan dokumentasi di lokasi penelitian serta instrumen yang dipakai untuk mendapatkan data dalam penelitian ini adalah peneliti sendiri karena peneliti merupakan alat pengumpul data utama.

Langkah-langkah penelitian ini menurut John Creswell dalam Raco yaitu; 1) mengidentifikasi masalah yang untuk menemukan kenyataan yang terjadi pada kehidupan bermasyarakat, 2) penelusuran kepustakaan yaitu dengan mengkaji literatur atau penelitian terdahulu terkait topik yang akan diteliti, 3) menentukan maksud dan tujuan utama dalam penelitian, 4) pengumpulan data yaitu menentukan informan dan mengumpulkan data yang berkaitan dengan masalah penelitian, 5) analisis dan penafsiran data yaitu peneliti menganalisis data yang tersusun, meringkas data, mengklarifikasi, mengelompokan dalam beberapa tema pembahasan kemudian ditfsirkan oleh peneliti hingga pada akhirnya menghasilkan suatu gagasan yang baru, dan yang terakhir 6) tahap pelaporan yaitu peneliti menggambarkan dan menuangkan hasil penelitian dalam sebuah laporan. Peneliti menggambarkan situasi, lingkungan, kehidupan bermasyarakat sosial secara luas dan mendalam. ${ }^{18}$

Ada beberapa teknik atau cara pengumpulan data dalam penelitian ini yaitu (1) teknik wawancara yaitu mewawancarai para informan yang ada di lokasi penelitian dengan berpedoman pada pertanyaan yang sudah disiapkan. Wawancara dilakukan secara terbuka, responsive dan tetap menghargai informan Wawancara disesuaikan dengan waktu dan kesibukan informan serta menggunakan pendekatan secara kekeluargaan. Semua jawaban informan dari setiap pertanyaan akan dicatat oleh peneliti., (2) angket yang diberikan kepada setiap informan untuk diisi atau dijawab, dan (3) teknik dokumentasi yaitu memanfaatkan berbagai dokumen yang memiliki keterkaitan dengan peran Uem Le'u dalam kehidupan masyarakat suku Amaf pada Sonaf Maubesi.

Sedangkan teknik analisis data yang digunakan dalam penelitian ini adalah teknik analisis deskriptif kualitatif. Teknik ini akan dikembangkan dengan cara verstheheninterpretative artinya semua data yang diperoleh dikelompokkan berdasarkan tema atau kategori kemudian dianalisis secara parsial berdasarkan tema dengan tujuan 
untuk menemukan makna dari data tersebut. Analisis ini lebih mengutamakan interpretasi terhadap data untuk memperoleh satu pemahaman secara utuh tentang jawaban dari rumusan masalah penelitian.

Analisis struktural fungsional juga digunakan untuk memahami dan memaknai berbagai makna dari setiap data yang berkaitan dengan peran Uem Le'u dalam kehidupan masyarakat suku Amaf pada Sonaf Maubesi. Data yang sudah dianalisis akan dideskripsikan secara naratif.

\section{HASIL TEMUAN DAN PEMBAHASAN}

Rumah sebagai tempat yang ditinggali sekelompok manusia dalam jangka waktu yang lama, telah mengalami berbagai perubahan. Perubahan yang terjadi dilihat pada bentuk, makna, fungsi serta nilai dari rumah tersebut. Namun rumah dalam kehidupan masyarakat berbudaya juga tidak dipandang sebatas tempat tinggal, tetapi dipandang dan diposisikan sebagai pandangan hidup serta ekspresi dari kehidupan suatu kelompok masyarakat itu sendiri. Rumah adat masyarakat di Nusa Tenggara Timur memiliki keberagaman dalam bentuk dan fungsi serta menyatu dalam kehidupan bermasyarakat. Suku-suku yang berada di Nusa Tenggara Timur memiliki rumah adat sebagai hasil budaya dengan beberapa bentuk yang sedikit berbeda. Namun pada umumnya setiap kelompok masyarakat atau suku memiliki rumah adat dengan bentuk bulat atau setengah lingkaran.

Rumah adat dalam kehidupan masyarakat NTT dipercaya sebagai tempat keramat atau bersemayamnya roh nenek moyang atau bersemayamnya sang pencipta kehidupan. Salah satunya adalah rumah adat yang juga disebut rumah keramat sebagai wujud budaya masyarakat di Kabupaten Timor Tengah Utara. Struktur sosial budaya masyarakat Kabupaten TTU terbagi dalam beberapa suku yang terstruktur dalam pembagian Sonaf. Sekian jumlah suku yang berada dalam suatu Sonaf memposisikan rumah adat dengan fungsi yang berbeda-beda, yang kemudian fungsi tersebut melebur dalam kehidupan bermasyarakat. Keberadaan rumah adat sebagai salah satu hasil budaya yang terbentuk dalam kehidupan masyarakat Indonesia khususnya di berbagai daerah NTT mulai memudar pengenalan dan pelestariannya. Hal ini disebabkan oleh perkembangan zaman dan iptek yang belum seimbang dengan pola pikir dan kehidupan bermasyarakat di sebagian besar daerah NTT. Sehingga memberi dampak pergeseran atau alih fungsi pada eksistensi rumah adat tersebut.

Eksistensi rumah adat sebagai salah satu hasil budaya yang terbentuk dalam kehidupan masyarakat Indonesia khususnya di berbagai daerah NTT mulai memudar pengenalan dan pelestariannya. Hal ini disebabkan oleh perkembangan zaman dan iptek yang belum seimbang dengan pola pikir dan kehidupan bermasyarakat di sebagian besar daerah NTT. Sehingga memberi dampak pergeseran atau alih fungsi pada eksistensi rumah adat tersebut. Pada beberapa bidang kehidupan masyarakat akan mengalami krisis pengenalan bahkan akan terjadi penurunan tingkat pelestarian rumah adat sebagai hasil kebudayaan. Generasi penerus atau generasi muda NTT khususnya masyarakat Timor Tengah Utara perlahan mulai memudar jika pengenalan 
akan hasil kebudayaan tidak lagi diperhatikan. Kekayaan budaya melalui hasil kebudayaan yang diturunkan dari generasi ke generasi harus diperkenalkan secara berkala.

Pada kehidupan sosial masyarakat TTU rumah adat tidak hanya sebagai tempat tinggal tetapi sebagai gambaran sistem sosial, budaya, ekonomi dan politik masyarakat sendiri. Rumah adat secara umum terbagi dalam 3 bagian yaitu Uem $L e^{\prime} u$, Uem Aluk Kabi dan Uem Pah. Selain itu sistem sosial masyarakat terdiri dari 3 suku besar. ${ }^{19}$ Sesuai dengan yang dikemukakan Alexander, tiap suku mempunyai cabang atau subklan. Suku-suku pada umumnya terbagi atas tiga kelompok besar yaitu Usif, Amaf dan Kolo Manu. Nama suku diturunkan menurut garis ayah (patrilineal). Ketiga suku besar ini memiliki suku-suku kecil di dalamnya. Setiap suku dalam pembagian ini memiliki peran atau fungsi tersendiri dalam setiap unsur kehidupan masyarakat.

Masyarakat dikategorikan dalam pembagian 3 Sonaf besar secara umum yaitu Sonaf Biboki, Sonaf Insana dan Sonaf Meomafo. Pada Sonaf Insana terdapat 2 Sonaf kecil yang menaungi kehidupan bermasyarakat dalam berbagai aspek.

Penelitian ini mendeskripsikan dan mengkaji kehidupan masyarakat yang berada pada sistem sosial salah satu Sonaf yang ada di Sonaf Insana yaitu Sonaf Maubesi yakni Peran Uem Le'u dalam kehidupan Suku Amaf di Sonaf Maubesi.

Bagan 1

Gambaran struktur/turunan kelompok suku di TTU

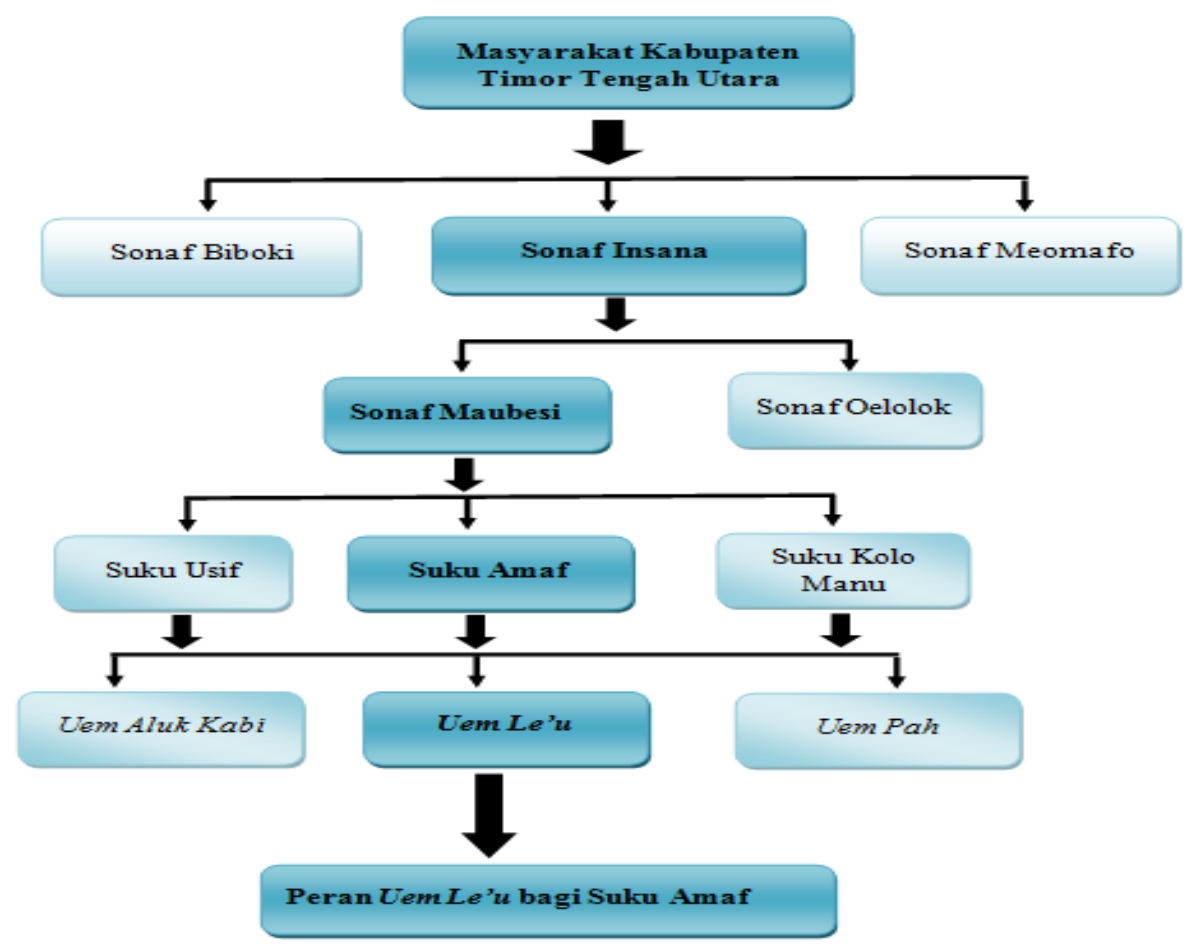

19 Usfinit, Alexander Un. 2003. Maubes-Insana: Salah satu masyarakat di timor dengan struktur adat yang unik. Yogyakarta: Kanisius. hal 8 
Fenomena yang terjadi pada kehidupan masyarakat suku Amaf yaitu adanya pergeseran fungsi bahkan terjadinya perubahan bentuk fisik rumah adat akibat perkembangan zaman maka penelitian ini akan menyajikan deskripsi dari salah satu hasil budaya yang patut dipertahankan sebagai identitas masyarakat. Rumah yang pada awal perkembangan kehidupan dipandang dan dianggap sebgai tempat yang skral serta sarat akan adat istiadat yang pantang untuk dilanggar, kini tidak menjadi suatu rutinitas keberlangsungan adat istiadat suku Amaf lagi.

Dalam aspek agama atau kepercayaan, masyarakat suku Amaf pada saat ini masih percaya bahwa Uem Le'u merupakan tempat bersemayamnya Tuhan yang dipercayai dan tempat tinggalnya para leluhur yang mendiami surga atau tempat peristirahatan terakhir. Tuhan yang merupakan pencipta dan pemelihara kehidupan masyarakat serta para leluhur yang mendoakan kehidupan masyarakat. Sehingga masih ada beberapa ritual kepercayaan yang dilaksanakan di tempat atau Uem Le'u tersebut. Sedangkan pada aspek sosial Uem $L e^{\prime} u$ masih merupakan tempat berkumpulnya masyarakat suku Amaf dari berbagai golongan atau strata masyarakat guna melaksanakan suatu upacara adat yang berkaitan dengan kepercayaan masyarakat setempat. Mulai dari ketua suku, atau ketua adat, para tuah-tuah adat serta masyarakat tergolong bawah selalu terlibat dalam berbagai pertemuan di Uem $l e^{\prime} u$. Selain itu adanya upacara adat seperti syukur panen dan persiapan menanampun terjadi di rumah adat tersebut.

\section{E. KESIMPULAN}

Masyarakat suku Amaf di Sonaf Maubesi Kecamatan Insana TTU masih memiliki perspektif yang sakral, yang sarat akan makna dan adat istiadat serta kepercayaan terhadap eksistensi Uem Le'u. Perspektif ini tidak hanya melekat dalam pola pikir masyarakat, bahkan sangat melekat pada kehidupan bermasyarakat. Dan Uem $L e^{\prime} u$ masih sangat dipercaya sebagai suatu hasil atau wujud budaya yang harus tetap terpelihara dan dilestarikan oleh masyarakat pada generasi ke generasi berikut. Selain itu Uem Le'u juga masih memiliki peran yang kental dalam kehidupan masyarakat. Peran tersebut Nampak pada aspek kehidupan sosial, kepercayaan, adat budaya masyarakat. Terbukti dengan masih dilaksanakan berbagai pertemuan dan upacara adat di Uem $L e^{\prime} u$. 


\section{REFERENSI:}

Arrafiani. (2012). Rumah Etnik Bali. Jakarta: Griya Kreasi.

A. B Sarjono, 2011. Arsitektur dalam perubahan kebudayaan. (online), Tersedia: Dtap.undip.ac.id/index.php/artikel/arsitektur-dalam-perubahan-kebudayaanstudi kasus (diunduh januari 2021)

Ariani, Luh Ni. (2014). Rumah Adat Suku Lamaholot Korke (Bentuk dan Fungsi). Dalam Jurnal Penelitian Sejarah dan Nilai Tradisional, 21(1): 47-56

Arch. A. (2012). Sejarah dan Perkembangan Arsitektur di Indonesia. (online), Tersedia: http://addyarchy07.blogspot.com/2012/01/sejarah-dan-perkembanganarsitektur di.html.\%20sumoharjo\%20,\%202012(diunduh: 18 september 2020)

Anra Yusdi dan Asyhadi. (2018). Architecture Varieties of Jambi Malay Traditional House: A study of architectural archeology in conserving cultural heritage and advancement of Jambi Malay culture. TITIAN Vol.2 No.2 Desember Hal 300-322

Boru, Jeky El. 2013. Perkembangan Arsitektur Vernakular Atoni Studi Kasus: Kawasan Istana Kerajaan Amarasi di Tunbaun, Kabupaten Kupang. Jurnal Arsitektur KOMPOSISI, 10, 3, 207-216

Dahliani. 2014. Eksistensi Rumah Tradisional Banjar Sebagai Identitas Kawasan Bersejarah di Kelurahan Kuin Utara,Banjarmasin. Jurnal MODUL, 14, 1, 08532877

D. Kristiani. 2014. Ensiklopedia Negeriku Rumah Adat. Jakarta: Bhuana Ilmu Populer

Djono., Utomo Tri Prasetyo., \& Subiyantoro Slamet. 2012. Nilai Kearifan Lokal Rumah Tradisional Jawa. Dalam Jurnal Humaniora, 24(3): 269-278.

Faisal, R.M., (2014). Pembangunan Aplikasi Magic Book Rumah Adat Tradisional Berbasis Augmented Reality. Bandung: Universitas Komputer.

Hutari, Fandy. 2017. Hiburan Masa Lalu dan Tradisional Lokal: Kumpulan Esai Seni, Budaya dan Sejarah Indonesia. Yogyakarta: INSISTPress.

Kabosu Mario.Y, Herman Joebagio dan Susanto. 2018. Arsitektur Rumah Adat Sonaf Bikomi Sanak pada Masyarakat Maslete Kabupaten Timor Tengah Itara Nusa Tenggara Timur. JTP2IPS, 3, 2,117-122

Liliweri, Alo. 2014. Pengantar Studi Kebudayaan. Bandung: Nusa Media.

M. Abdul Karim, 2009, Sejarah Pemikiran dan Peradaban Islam, Yogyakarta: Pustaka BOOK Publisher, 2009, hlm.34.

Sabono Ferdy. (2017). Konsep Rumah Tumbuh Pada Rumah Adat Tradisional Dusun Doka, Nusa Tenggara Timur. MEDIA MATRASAIN Vil.14 No.1,Maret ISSN 18581137

Usfinit, Alexander Un. 2003. Maubes-Insana: Salah satu masyarakat di timor dengan struktur adat yang unik. Yogyakarta: Kanisius. 
R. Prabowo, T. Listyorini, and A. Jazuli. 2011. Pengenalan Rumah Adat Indonesia Berbasis Augmented Reality dengan Memanfaatkan KTP Sebagai Marker. Jurnal SNATIF, 2,51 58

Raco,J.R., (2010). Metode Penelitian Kualitatif: Jenis,Karakteristik Dan Keunggulan. Jakarta: Grasindo.

Halim. 2011. Perkembangan Rumah Tradisional Muna. Unity Jurnal Arsitek, 1, 2, 68-79 